\section{Farming will only be sustainable when local people are truly involved}

Sir - Yaalon in Correspondence (Nature $405,993 ; 2000)$ refers to my earlier Correspondence in which I argued that local farmers could feed Africa if they were given the chance (Nature 404, 431; 2000).

I agree with Yaalon that available data on land resources are not always reliable. Their accuracy depends on data provided by national authorities. The UN Food and Agriculture Organization, which collects and publishes this material, is the only source for this worldwide information and is not to blame for any inaccuracies.

The comparatively low agricultural production in Africa today is not due to population pressure, the subsequent shortening of the fallow period and the depletion of soil nutrient status, as is generally believed. As I pointed out, there is a growing shortage of labour in rural areas as people migrate to the cities, and hence a reduction in cultivated acreage.

Technical solutions are well known: for many years agricultural development projects have focused on ways to increase production including improved soil management, intensification and diversification of the cropping pattern, adapted farming systems, restoration of the soil nutrient status, and so on. That these have not been implemented is often owing to socio-economic or cultural constraints.

Fertilizer is a good technical solution to the problem of poor soils, for example. But for local farmers, it still represents an extra cost which most cannot pay.

Yaalon's suggestion that "current subsidy and overseas aid should be used to provide the fertilizers and improved planting materials that are needed" is not a sustainable solution, as it replaces the structural problem of food aid with another structural problem of fertilizer aid. Once the the free supply stops, farmers return to their traditional system.

Yaalon's vision that "many locally trained soil and extension specialists living in the region are needed to transform the economy from one of small rural farmers to one of market food production" has not been successful in Africa. Almost all efforts over the past 20 years have now been dismantled or vastly reduced, despite efforts to involve local expertise.

Substantial rethinking about aid is needed, to switch from a top-down to a bottom-up approach. The key questions are how to increase the sustainability of technical assistance and how to involve local people in follow-up activities. Examples of the former include supplying farm implements and creating a small credit system; setting up a cooperative network for marketing agricultural products; attempting to end the practice of denying access to land by women, and so on. If the stakeholders are involved at all stages - ensuring that the project meets their demands - and their knowledge is included (updated if necessary), they are very much more likely to continue the activities after the project ends.

Yaalon's dedicated soil scientists might be helpful, not necessarily because of their technical skills but as facilitators for local people, to understand their problems and to use their advice. The soil scientists will learn that local farmers are usually well aware of their problems, and even know how to solve them, but generally lack the external support.

In my opinion, increasing food production in Africa is primarily a question of incentives and marketing assistance to farmers' communities. Once farmers are guaranteed a reasonable return for their work they will engage in efforts to produce more. With the extra earnings they will buy fertilizer, and break the vicious circle of subsistence farming. Willy H. Verheye

Fund for Scientific Research Flanders, Department of Geography, University of Gent, Krijgslaan 281, B-9000 Gent, Belgium

\section{Guidelines work better than animal welfare law}

Sir-Your Opinion article, "In defence of animal research" (Nature 407, 659; 2000), incorrectly states that the Federation of American Societies for Experimental Biology (FASEB) urges dispensing with a definition of distress for animals used in research, testing and teaching.

In a letter sent to the US Department of Agriculture (USDA) on 18 October, FASEB states that guidelines for the recognition of distress would be useful, but should not be included in USDA regulations or policy manuals because a single, standardized definition of distress would not help institutions to recognize, minimize or report animal distress across species and situations.

FASEB believes that local Institutional Animal Care and Use Committees (IACUCs) should take responsibility in this area and foster a partnership among scientists, veterinarians, veterinary technicians, animal husbandry staff, government and professional associations.

Rather than being a reactionary argument, as asserted in your editorial, the FASEB position is based on a careful review of data from the scientific study of pain and distress in animals, and discussions with laboratory animal-care specialists from various disciplines including physiology, psychology and neuroscience.

Further, FASEB's recommendations are designed to protect the animals that scientists are indeed privileged to use. They acknowledge that a local IACUC is the best qualified to make decisions about the animals in its care, given their intimate knowledge of multiple factors affecting an animal's well-being.

Although FASEB cannot claim that all researchers are united in their opposition to including rats, mice and birds under the Animal Welfare Act, it represents 21 research societies with more than 60,000 members. Your editorial mentions Public Health Service regulations: more than $90 \%$ of the rats, mice and birds used for research in the United States are already covered by voluntary accreditation and/or Public Health Service policy. The research community is therefore objecting to redundant regulations, and not the principle of regulating the use of animals.

FASEB believes that modifications to USDA regulations should benefit animals, promote research and reduce administrative cost and regulatory burden. Including rats, mice and birds under the Animal Welfare Act would not accomplish these goals.

FASEB's complete statement is at http://www.faseb.org/opar/news/docs/ usda9x22.html. We encourage dialogue with the scientific community on the evolving standards for determining pain and distress in laboratory animals.

Mary J. C. Hendrix

FASEB, 9650 Rockville Pike, Bethesda, Maryland 20814-3998, USA

\section{Wrong signals about alliance's scope and aim}

Sir - I would like to correct an error in your Opinion article "Systems Biology's Multiple Maths” (Nature 407, 819; 2000) about the approach and the scope of the Alliance for Cellular Signaling. Our focus is limited to $G$ protein-regulated and related (interacting) cellular signalling systems, not "every protein-protein interaction in two cell types". We seek quantitative information about these systems at all levels - not just detection of interactions between proteins. Further details can be found on our website, http://afcs.swmed.edu; see also Nature 402, 219; 1999.

\section{Alfred G. Gilman}

Department of Pharmacology, University of Texas Southwestern Medical Center, Dallas,

Texas 75390, USA 